\title{
New Sulphated Flavonoids and Larvicidal Activity of Helicteres velutina K. Schum (Sterculiaceae)
}

\author{
Diégina A. Fernandes ${ }^{1}$, Maria S. R. Souza ${ }^{1}$, Yanna C. F. Teles ${ }^{2}$, Louise H. G. Oliveira $^{3}$, \\ Jéssica B. Lima ${ }^{4}$, Adilva S. Conceição ${ }^{4}$, Fabíola C. Nunes ${ }^{3}$, Tania M. S. Silva ${ }^{5}$ and \\ Maria de Fátima Vanderlei de Souza ${ }^{1,6, *}$
}

1 Post Graduation Program in Bioactive Natural and Synthetic Products, Federal University of Paraíba, João Pessoa 58051-900, PB, Brazil; diegina@ltf.ufpb.br (D.A.F.); sallett@ltf.ufpb.br (M.S.R.S.)

2 Department of Chemistry and Physics, Agrarian Sciences Center, Federal University of Paraíba, Areia 58397-000, PB, Brazil; yanna@cca.ufpb.br

3 Biotechnology Center, Federal University of Paraíba, João Pessoa 58051-900, PB, Brazil; louiseguimaraes@outlook.com (L.H.G.O.); fabiola@cbiotec.ufpb.br (F.C.N.)

4 Post Graduation Program in Plant Biodiversity, Department of Education, University of the State of Bahia, Paulo Afonso 41150-000, BA, Brazil; jessica.bl@hotmail.com (J.B.L.); adilva.souza@gmail.com (A.S.C.)

5 Department of Molecular Sciences, Rural Federal University of Pernambuco, Campus Dois Irmãos, Recife 52171-900, PE, Brazil; sarmentosilva@gmail.com

6 Post Graduation in Development and Technological Innovation in Medicines, Federal University of Paraíba, João Pessoa 58051-900, PB, Brazil

* Correspondence: mfvanderlei@ltf.ufpb.br; Tel./Fax: +55-83-3216-7351

Received: 9 June 2018; Accepted: 22 August 2018; Published: 27 October 2018

\begin{abstract}
Helicteres velutina K. Schum (Sterculiaceae), commonly known in Brazil as 'pitó', is traditionally used by indigenous peoples as insecticides and repellents. The present work reports on the the phytoconstituents from aerial parts of H. velutina and evaluation of the larvicidal potential of its extract. The compounds were isolated using chromatographic techniques and identified by NMR, IR and LC-HRMS. This study led to the isolation of a fatty acid, one aliphatic alcohol, four chlorophyll derivatives, one steroid, triterpenes, a lignan, and flavonoids, highlighting the new compounds in the literature, 5, $4^{\prime}$-di-hydroxy-7-methoxy-8-O-sulphate flavone (mariahine) (15a) and 5,3'-di-hydroxy-7, $4^{\prime}$-dimethoxy-8-O-sulphate flavone (condadine) (15b). The work presented here contributes to the chemotaxonomic knowledge of the Sterculiaceae family by describing the occurrence of sulphated flavonoids in this family for the first time. The crude ethanolic extract of $H$. velutina featured robust larvicidal activity against Aedes aegypti larvae, showing that the extract can be useful as a domestic larvicide, just as indicated by traditional use, to combat $A$. aegypti, a vector insect of severe viral diseases, such as dengue and Zika.
\end{abstract}

Keywords: Helicteres velutina; Sterculiacaeae; sulphated flavonoids; larvicidal activity; Aedes aegypti

\section{Introduction}

The Sterculiaceae family is composed of 70 genera and approximately 1500 species spread all over the world, with 14 genera and 165 species found in Brazil [1,2]. According to the system, Angiosperm Phylogeny Group (APG) IV, the families Sterculiaceae, Bombacaceae and Tiliaceae were insert into the family Malvaceae sensu lato [3]. The Helicteres genus has a predominantly pantropical distribution in American and Asian countries. There is no record of the species occurring in both continents [4]. Phytochemical studies on Helicteres species have demonstrated the presence of terpenes [5], steroids [6], alkaloids [7], saponins [8] and flavonoids [9]. Many Helicteres species are traditionally used as medicines, for example, Helicteres sacarolha is used to treat hypertension 
and ulcers [9] and Helicteres angustifólia has been employed as an analgesic and anti-inflammatory herb [6]. The traditional uses of Helicteres species have raised scientific interest in their pharmacological activities. Helicteres isora has been shown to possess antioxidant, antimicrobial and hepatoprotective activities [8], and H. angustifólia was active against the hepatitis B virus [10].

Helicteres velutina, popularly known as 'pitó', is an endemic species from Brazil. The plant is traditionally used as an insect repellent by indigenous peoples from the Pankararé tribe in Paulo Afonso, Bahia [11]. There are literature reports of the biological activities of roots and stem extracts against the larvae of Aedes aegypti [11]. However, no subsequent biological studies were carried out and no phytochemical studies are available.

Considering the lack of phytochemical information and the interesting uses of H. velutina, this work aims to isolate and identify compounds from their aerial parts and evaluate the larvicidal activity of the obtained extract against larvae of A. aegypti.

\section{Results}

\subsection{Identification of Compounds}

The compounds identified from aerial parts of $H$. velutina are shown in Figure 1 . They were identified by 1D and 2D NMR data and comparisons with the literature (spectra available as Supplementary material).

Fraction 15 was analyzed by NMR, IR and LC-HRMS. It was found to be a mixture of three compounds $(\mathbf{1 4}, \mathbf{1 5 a}$ and $\mathbf{1 5 b})$ and their spectral data are presented in Table 1.

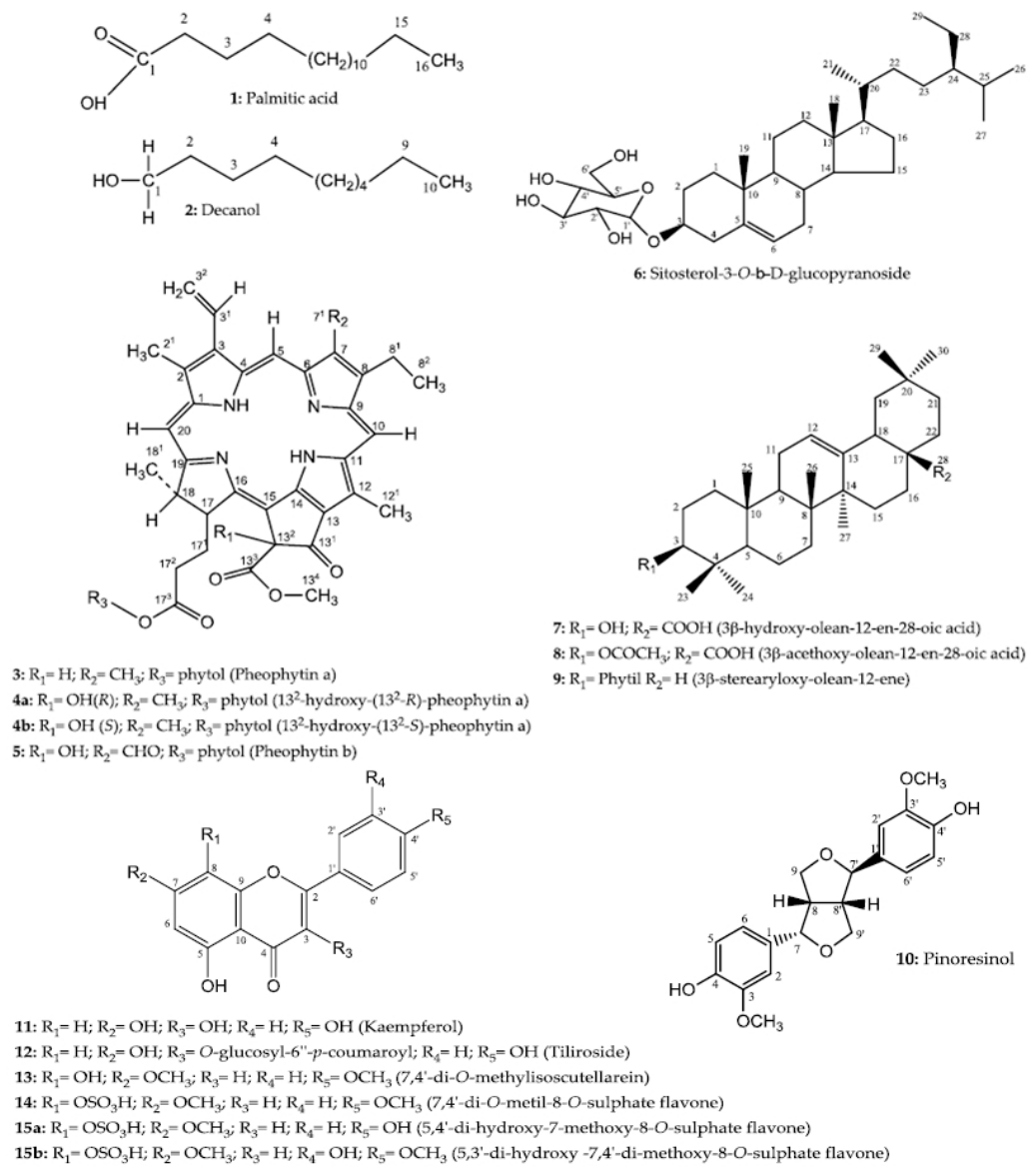

Figure 1. Compounds isolated from $H$. velutina. 
Table 1. NMR data $\left({ }^{1} \mathrm{H},{ }^{13} \mathrm{C}\right.$ and HMBC- Heteronuclear Multiple Bond Correlation) of 14, 15a and 15b ( $\delta$, DMSO- $d_{6}, 500$ and 125 MHz).

\begin{tabular}{|c|c|c|c|c|c|c|c|c|c|}
\hline \multirow{2}{*}{$\mathrm{C}$} & \multicolumn{3}{|c|}{14} & \multicolumn{3}{|c|}{$15 a$} & \multicolumn{3}{|c|}{$15 b$} \\
\hline & $\delta_{\mathrm{H}}$ & $\delta_{\mathrm{c}}$ & НMBC & $\delta_{\mathbf{H}}$ & $\delta_{C}$ & НMBC & $\delta_{H}$ & $\delta_{\mathrm{c}}$ & HMBC \\
\hline 2 & - & 164.3 & - & - & 164.8 & - & - & 164.7 & _ \\
\hline 3 & $6.74(\mathrm{~s}, 1 \mathrm{H})$ & 101.8 & $\mathrm{C}-2$ & $6.74(\mathrm{~s}, 1 \mathrm{H})$ & 101.8 & $C-2, C-1^{\prime}$ & $6.69(\mathrm{~s}, 1 \mathrm{H})$ & 102.7 & - \\
\hline 4 & - & 182.6 & - & - & 182.6 & - & - & 182.6 & - \\
\hline 5 & - & - & - & - & - & - & - & - & \\
\hline 6 & $6.48(\mathrm{~s}, 1 \mathrm{H})$ & 95.8 & - & $6.48(\mathrm{~s}, 1 \mathrm{H})$ & 95.8 & - & $6.48(\mathrm{~s}, 1 \mathrm{H})$ & 95.8 & - \\
\hline 7 & - & 159.1 & - & - & 159.1 & & - & 159.1 & - \\
\hline 8 & - & 123.1 & - & - & 123.2 & - & - & 123.2 & - \\
\hline 9 & - & 148.8 & - & - & 148.8 & - & - & 148.8 & - \\
\hline 10 & - & 104.7 & - & - & 104.7 & - & - & 104.7 & - \\
\hline $1^{\prime}$ & - & 123.6 & - & - & 121.6 & - & - & 123.6 & - \\
\hline $2^{\prime}$ & $8.26(\mathrm{~d}, J=1.75$ e $9.0 \mathrm{~Hz}, 2 \mathrm{H})$ & 129.3 & $C-2, C-4^{\prime}, C-6^{\prime}$ & $8.13(\mathrm{~d}, J=8.9 \mathrm{~Hz}, 2 \mathrm{H})$ & 129.3 & $C-2, C-4^{\prime}, C-6^{\prime}$ & $7.56(\mathrm{~d}, J=2.2 \mathrm{~Hz} 1 \mathrm{H})$ & 113.8 & $\mathrm{C}-3^{\prime}, \mathrm{C}-4^{\prime}, \mathrm{C}-6^{\prime}$ \\
\hline $3^{\prime}$ & $7.09(\mathrm{~d}, J=9.0 \mathrm{~Hz}, 2 \mathrm{H})$ & 116.2 & C $-4^{\prime}, C-1^{\prime}$ & $6.86(\mathrm{~d}, J=8.8 \mathrm{~Hz}, 2 \mathrm{H})$ & 116.0 & $C-4^{\prime}, C-1^{\prime}, C-5^{\prime}$ & - & 146.8 & - \\
\hline $4^{\prime}$ & $\left.1.07\left(a_{1}\right)-1.0112,211\right)$ & 162.7 & - & $0.00(\mathrm{a}, j-0.012,211)$ & 162.3 & - & - & 151.6 & - \\
\hline $5^{\prime}$ & $7.09(\mathrm{~d}, J=9.0 \mathrm{~Hz}, 2 \mathrm{H})$ & 116.2 & $\mathrm{C}-4^{\prime}, \mathrm{C}-1^{\prime}$ & $6.86(\mathrm{~d}, J=8.8 \mathrm{~Hz}, 2 \mathrm{H})$ & 116.0 & $\mathrm{C}-4^{\prime}, \mathrm{C}-1^{\prime}$ & $7.07(\mathrm{~d}, J=8.5 \mathrm{~Hz}, 1 \mathrm{H})$ & 111.8 & $C-1^{\prime}$ \\
\hline $6^{\prime}$ & $8.26(\mathrm{~d}, J=1.75$ e $9.0 \mathrm{~Hz}, 2 \mathrm{H})$ & 129.3 & $C-2, C-4^{\prime}$ & $8.13(\mathrm{~d}, J=8.9 \mathrm{~Hz}, 2 \mathrm{H})$ & 129.3 & $\mathrm{C}-2, \mathrm{C}-4^{\prime}$ & $7.83(\mathrm{dd}, J=2.2$ e $8.5 \mathrm{~Hz}, 1 \mathrm{H})$ & 119.8 & $C-2^{\prime}, C-4^{\prime}$ \\
\hline $\mathrm{OCH}_{3}-4^{\prime}$ & $3.84(\mathrm{~s}, 3 \mathrm{H})$ & 56.4 & - & - & - & - & $3.85(\mathrm{~s}, 3 \mathrm{H})$ & 55.7 & - \\
\hline $\mathrm{OCH}_{3}-7$ & $3.82(\mathrm{~s}, 3 \mathrm{H})$ & 56.4 & - & $3.82(\mathrm{~s}, 3 \mathrm{H})$ & 56.4 & - & $3.82(\mathrm{~s}, 3 \mathrm{H})$ & 56.4 & \\
\hline $\mathrm{OH}-5$ & $12.91(\mathrm{~s}, 1 \mathrm{H})$ & - & - & $12.91(\mathrm{~s}, 1 \mathrm{H})$ & - & - & $12.91(\mathrm{~s}, 1 \mathrm{H})$ & - & - \\
\hline
\end{tabular}




\section{Spectral Data}

Palmitic acid (1), white solid; IR (KBr, cm $\left.{ }^{-1}\right)$ : 3500, 2953, 2848, 1707, 1472, 1300. ${ }^{1} \mathrm{H}-\mathrm{NMR}(400 \mathrm{MHz})$ $\left(\mathrm{CDCl}_{3}\right) \delta: 2.34(\mathrm{t}, J=7.4 \mathrm{~Hz}, 2 \mathrm{H}, \mathrm{H}-2), 1.63(\mathrm{q}, 2 \mathrm{H}, \mathrm{H}-15), 1.25$ (bs), $0.87(\mathrm{t}, J=6.6 \mathrm{~Hz}, \mathrm{H}-16) .{ }^{13} \mathrm{C}-\mathrm{NMR}$ ( $\left.8, \mathrm{CDCl}_{3}, 100 \mathrm{MHz}\right): 178.6$ (C-1), 33.9 (C-2), 32.0 (C-4), 29.8 (C-5, C-12, C-13, C-14), 29.5 (C-11), 29.7 (C-6), 29.5 (C-7), 29.4 (C-8), 29.2 (C-9, C-10), 24.8 (C-3), 22.8 (C-15), 14.2 (C-16). The ${ }^{1} \mathrm{H}-$ and ${ }^{13} \mathrm{C}-\mathrm{NMR}$ spectral data were consistent with published data [12].

Decanol (2), white solid; IR (KBr, cm $\left.{ }^{-1}\right): 3500,2954,2848,1472 .{ }^{1} \mathrm{H}-\mathrm{NMR}(400 \mathrm{MHz})\left(\mathrm{CDCl}_{3}\right) \delta: 3.63(\mathrm{t}$, $J=6.56 \mathrm{~Hz}, 2 \mathrm{H}, 1 \mathrm{H}), 1.25-1.59(\mathrm{~m}), 0.87(\mathrm{t}, J=6.72 \mathrm{~Hz}, 3 \mathrm{H}, \mathrm{H}-10) .{ }^{13} \mathrm{C}-\mathrm{NMR}(100 \mathrm{MHz})\left(\mathrm{CDCl}_{3}\right) \delta: 63.0$ (C-1), 32.7 (C-2), 29.3 (C-4), 29.4 (C-5), 29.6, 29.7, 31.9, 25.7 (C-3), 22.6 and 14.1 (C-10). The ${ }^{1} \mathrm{H}-$ and ${ }^{13} \mathrm{C}-\mathrm{NMR}$ data were in accordance with published data [12].

Pheophytin a (3), $13^{2}$-hydroxy-(132-S)-pheophytin a (4a), $13^{2}$-hydroxy-( $\left.13^{2}-R\right)$-pheophytin a (4b), Pheophytin $b(5)$, green solids, were identified by 1D and 2D NMR and comparison with the literature [12-14].

Sitosterol-3-O- $\beta$-D-glucopyranoside (6), colorless crystal, was identified by $1 \mathrm{D}$ and 2D NMR and comparison with the literature [15].

3- $\beta$-hydroxy-olean-12-en-28-oic acid (7), white powder; ${ }^{1} \mathrm{H}-\mathrm{NMR}(500 \mathrm{MHz})\left(\mathrm{C}_{5} \mathrm{D}_{5} \mathrm{~N}\right) \delta: 0.99(\mathrm{~s}, 3 \mathrm{H}$, Me-26), 1.22 (s, 3H, Me-24), 0.88 (s, 3H, Me-29), 0.93 (s, 3H, Me-25), 1.01 (s, 3H, Me-30), 1.01 (s, 3H, Me-23), 1.26 (s, 3H, Me-27), 3.29 (dd, 1H, H-18), 3.43 (dd, 1H, J = 5.6 e 10. 5 Hz, H-3), 5.48 (dd, 1H, $J=3.4 \mathrm{~Hz}, \mathrm{H}-12) ;{ }^{13} \mathrm{C}-\mathrm{NMR}(125 \mathrm{MHz})\left(\mathrm{C}_{5} \mathrm{D}_{5} \mathrm{~N}\right)$ 8: $16.5(\mathrm{C}-24), 15.5$ (C-25), 17.4 (C-26), 18.7 (C-6), 23.6 (C-11), 23.7 (C-16), 23.7 (C-30), 26.1 (C-27), 28.0 (C-2), 28.7 (C-23), 30.9 (C-20), 33.1 (C-22), 33.1 (C-29), 33.2 (C-7), 34.1 (C-21), 37.7 (C-10), 38.8 (C-1), 39.3 (C-4), 39.7 (C-8), 41.9 (C-18), 42.1 (C-14), 46.4 (C-19), 48.0 (C-9), 55.7 (C-5), 78.0 (C-3), 122.5 (C-12), 144.8 (C-13), 180.2 (C-28). The ${ }^{1} \mathrm{H}-$ and ${ }^{13} \mathrm{C}-\mathrm{NMR}$ spectral data were consistent with published data [16].

3- $\beta$-acethoxy-olean-12-en-28-oic acid (8), white powder; ${ }^{1} \mathrm{H}-\mathrm{NMR}(400 \mathrm{MHz})\left(\mathrm{CDCl}_{3}\right) \delta: 0.73(\mathrm{~s}, 3 \mathrm{H}$, Me-26), 0.85 (s, 3H, Me-24), 0.91 (s, 3H, Me-29), 0.89 (s, 3H, Me-25), 0.93 (s, 3H, Me-30), 0.84 (s, 3H, Me-23), 1.11 (s, 3H, Me-27), 2.80 (dd, 1H, H-18), 4.49 (t, 1H, J = 8.5 Hz, H-3), 5.25 (dd, 1H, J = $3.4 \mathrm{~Hz}$, $\mathrm{H}-12) ; 2.03$ (s, 3H, OAc); ${ }^{13} \mathrm{C}-\mathrm{NMR}\left(8, \mathrm{CDCl}_{3}, 100 \mathrm{MHz}\right): 16.7$ (C-24), 15.5 (C-25), 17.2 (C-26), 18.2 (C-6), 22.9 (C-11), 23.6 (C-16), 23.7 (C-30), 26.0 (C-27), 23.5 (C-2), 28.1 (C-23), 30.7 (C-20), 32.5 (C-22), 33.1 (C-29), 32.6 (C-7), 33.9 (C-21), 37.8 (C-10), 38.1 (C-1), 37.8 (C-4), 39.3 (C-8), 41.7 (C-18), 41.7 (C-14), 45.9 (C-19), 47.6 (C-9), 55.4 (C-5), 81.0 (C-3), 122.7 (C-12), 143.7 (C-13), 184.6 (C-28), 171.2 (OAc). The ${ }^{1} \mathrm{H}-$ and ${ }^{13} \mathrm{C}-\mathrm{NMR}$ spectral data were consistent with published data [17].

3- $\beta$-sterearyloxy-olean-12-ene (9), white powder; ${ }^{1} \mathrm{H}-\mathrm{NMR}(400 \mathrm{MHz})\left(\mathrm{CDCl}_{3}\right) \delta: 0.86\left(\mathrm{~s}, 6 \mathrm{H}, \mathrm{Me}-28,18^{\prime}\right)$, 0.87 (s, 6H, Me-23, 24), 0.95 (s, 3H, Me-25), 1.10 (s, 3H, Me-26), 0.96 (s, 3H, Me-27), 0.83 (s, 6H, Me-29, 30), 1,63 (m, H-3'), 2.30 (d, 2H, J = 7.8 Hz, H-2'), 1.25 (s, H-4' a 17') 4.59 (dd, $1 \mathrm{H}, J=4.2,7.3 \mathrm{~Hz}, \mathrm{H}-3)$, $5.23(\mathrm{t}, J=3.6 \mathrm{~Hz}, \mathrm{H}-12) ;{ }^{13} \mathrm{C}-\mathrm{NMR}\left(\delta, \mathrm{CDCl}_{3}, 100 \mathrm{MHz}\right): 16.9$ (C-24), $15.6(\mathrm{C}-25), 17.2$ (C-26), 18.5 (C-6), 23.9 (C-11), 27.1 (C-16), 23.8 (C-30), 26.1 (C-27), 23.5 (C-2), 28.0 (C-23), 31.2 (C-20), 47.3 (C-22), 33.4 (C-29), 32.6 (C-7), 34.8 (C-21), 36.5 (C-10), 38.7 (C-1), 37.2 (C-4), 40.5 (C-8), 47.6 (C-18), 41.0 (C-14), 46.9 (C-19), 47.9 (C-9), 55.8 (C-5), 80.6 (C-3), 122.1 (C-12), 144.5 (C-13), 28.4 (C-28), 173.8 (C-1'), 35.0 (C-2'), $25.3\left(\mathrm{C}-3^{\prime}\right), 29.3\left(\mathrm{C}-4^{\prime}\right), 29.4\left(\mathrm{C}-5^{\prime}\right), 29.5\left(\mathrm{C}-6^{\prime}\right), 29.7\left(\mathrm{C}-7^{\prime}\right), 29.8\left(\mathrm{C}-8^{\prime}\right.$ a C-13') $29.8\left(\mathrm{C}-14^{\prime}\right), 29.6$ $\left(\mathrm{C}-15^{\prime}\right), 32.0\left(\mathrm{C}-16^{\prime}\right), 22.8\left(\mathrm{C}-17^{\prime}\right), 12.2\left(\mathrm{C}-18^{\prime}\right)$. The ${ }^{1} \mathrm{H}-$ and ${ }^{13} \mathrm{C}-\mathrm{NMR}$ spectral data were consistent with published data [18].

Pinoresinol (10), yellowish oil; ${ }^{1} \mathrm{H}-\mathrm{NMR}(400 \mathrm{MHz})\left(\mathrm{CD}_{3} \mathrm{COD}_{3}\right) \delta_{\mathrm{H}}: 6.98\left(\mathrm{~d}, J=1.9 \mathrm{~Hz}, 2 \mathrm{H}, \mathrm{H}-2,2^{\prime}\right), 6.78$ $\left(\mathrm{d}, J=8.1 \mathrm{~Hz}, 2 \mathrm{H}, \mathrm{H}-5,5^{\prime}\right) 6.83\left(\mathrm{dd}, J=8.1 \mathrm{e} 2 \mathrm{~Hz}, 2 \mathrm{H}, \mathrm{H}-6,6^{\prime}\right), 4.66\left(\mathrm{~d}, J=4.3 \mathrm{~Hz}, 2 \mathrm{H}, \mathrm{H}-7,7^{\prime}\right), 3.08(\mathrm{~m}$, $\left.2 \mathrm{H}, \mathrm{H}-8,8^{\prime}\right), 4.20\left(\mathrm{dd}, J=9 \mathrm{~Hz}, 2 \mathrm{H}, \mathrm{H}-9,9^{\prime}\right), 3.78\left(\mathrm{dd}, J=9.1 \mathrm{~Hz}, 2 \mathrm{H}, \mathrm{H}-9,9^{\prime}\right), 3.84\left(\mathrm{~s}, 6 \mathrm{H}, \mathrm{OMe}-3,3^{\prime}\right)$; ${ }^{13} \mathrm{C}-\mathrm{NMR}\left(\delta, \mathrm{CD}_{3} \mathrm{COD}_{3}, 100 \mathrm{MHz}\right): 134.1\left(\mathrm{C}-1,1^{\prime}\right), 110.6\left(\mathrm{C}-2,2^{\prime}\right), 148.4\left(\mathrm{C}-3,3^{\prime}\right), 146.8\left(\mathrm{C}-4,4^{\prime}\right), 115.5$ $\left(\mathrm{C}-5,5^{\prime}\right), 119.7\left(\mathrm{C}-6,6^{\prime}\right), 86.7\left(\mathrm{C}-7,7^{\prime}\right), 55.3\left(\mathrm{C}-8,8^{\prime}\right), 72.3\left(\mathrm{C}-9,9^{\prime}\right), 56.2\left(\mathrm{C}-3,3^{\prime}\right)$. The ${ }^{1} \mathrm{H}-$ and ${ }^{13} \mathrm{C}-\mathrm{NMR}$ spectral data were in agreement with literature data [19]. 
Kaempferol (11), yellow powder: ${ }^{1} \mathrm{H}-\mathrm{NMR}(500 \mathrm{MHz})\left(\mathrm{CD}_{3} \mathrm{OD}\right), \delta_{\mathrm{H}}: 6.17(\mathrm{~d}, J=2.0 \mathrm{~Hz}, 1 \mathrm{H}), 6.39(\mathrm{~d}$, $J=2.0 \mathrm{~Hz}, 1 \mathrm{H}), 8.09\left(\mathrm{~d}, J=9.0 \mathrm{~Hz}, 2 \mathrm{H}, \mathrm{H}-2^{\prime}, 6^{\prime}\right), 6.90\left(\mathrm{~d}, J=9.0 \mathrm{~Hz}, 2 \mathrm{H}, \mathrm{H}-3^{\prime}, 5^{\prime}\right) ;{ }^{13} \mathrm{C}-\mathrm{NMR}(125 \mathrm{MHz}$, $\left.\mathrm{CD}_{3} \mathrm{OD}\right): 148.2$ (C-2), 137.3 (C-3), 177.5 (C-4), 162.7 (C-5), 99.4 (C-6), 165.7 (C-7), 94.6 (C-8), 158.4 (C-9), $104.7(\mathrm{C}-10), 123.9\left(\mathrm{C}-1^{\prime}\right), 130.9\left(\mathrm{C}-2^{\prime}-6^{\prime}\right), 115.7\left(\mathrm{C}-3^{\prime}-5^{\prime}\right), 160.7\left(\mathrm{C}-4^{\prime}\right)$. The ${ }^{1} \mathrm{H}-$ and ${ }^{13} \mathrm{C}-\mathrm{NMR}$ spectral data were in agreement with literature data [20].

Tiliroside (12), yellow powder; ${ }^{1} \mathrm{H}-\mathrm{NMR}(500 \mathrm{MHz})\left(\mathrm{DMSO}-d_{6}\right) \delta_{\mathrm{H}}: 12.54(\mathrm{~s}, 5-\mathrm{OH}), 6.11(d, J=2.0$ $\mathrm{Hz}, \mathrm{H}-6), 6.35(d, J=2.0 \mathrm{~Hz}, \mathrm{H}-8), 7.97\left(d, J=8.8 \mathrm{~Hz}, \mathrm{H}-2^{\prime} / 6^{\prime}\right), 6.84\left(d, J=8.8 \mathrm{~Hz}, \mathrm{H}-3^{\prime} / 5^{\prime}\right), 5.43(d$, $\left.J=7.5 \mathrm{~Hz}, \mathrm{H}-1^{\prime \prime}\right), 3.14-3.26\left(m, \mathrm{H}-2^{\prime \prime}, 3^{\prime \prime}, 4^{\prime \prime}, 5^{\prime \prime}\right), 4,27\left(\mathrm{dd}, J=2.0\right.$ e $\left.12.0 \mathrm{~Hz} ; 1 \mathrm{H} \mathrm{H}-6^{\prime \prime}\right)$ e $4,02(\mathrm{dd}, J=6.5$ e $\left.12.0 \mathrm{~Hz} 1 \mathrm{H}, \mathrm{H}-6^{\prime \prime}\right) 7.35\left(d, J=8.5 \mathrm{~Hz}, \mathrm{H}-2^{\prime \prime \prime} / 6^{\prime \prime \prime}\right), 6.77\left(d, J=8.5 \mathrm{~Hz}, \mathrm{H}-3^{\prime \prime \prime} / 5^{\prime \prime \prime}\right), 7.33(d, J=15.5 \mathrm{~Hz}$, H-7'"'), $6.09\left(d, J=16 \mathrm{~Hz}, \mathrm{H}-8^{\prime \prime \prime}\right) ;{ }^{13} \mathrm{C}-\mathrm{NMR}\left(125 \mathrm{MHz}, \mathrm{DMSO}-d_{6}\right): 156.4(\mathrm{C}-2), 133.0$ (C-3), 177.3 (C-4), 161.1 (C-5), 98.8 (C-6), 164.5 (C-7), 93.7 (C-8), 156.3 (C-9), 103.7 (C-10), 120.7 (C-1'), 130.1 (C-2' / 6'), $115.7\left(\mathrm{C}-3^{\prime} / 5^{\prime}\right), 159.9\left(\mathrm{C}-4^{\prime}\right), 101.0\left(\mathrm{C}-1^{\prime \prime}\right), 74.2\left(\mathrm{C}-2^{\prime \prime}\right), 76.2\left(\mathrm{C}-3^{\prime \prime}\right), 69.9\left(\mathrm{C}-4^{\prime \prime}\right), 74.1\left(\mathrm{C}-5^{\prime \prime}\right), 62.9\left(\mathrm{C}-6^{\prime \prime}\right)$, $124.9\left(\mathrm{C}-1^{\prime \prime \prime}\right), 130.7\left(2^{\prime \prime \prime}, 6^{\prime \prime \prime}\right), 115.0\left(\mathrm{C}-3^{\prime \prime \prime}, 5^{\prime \prime \prime}\right), 159.7\left(\mathrm{C}-4^{\prime \prime \prime}\right), 144.5\left(\mathrm{C}-7^{\prime \prime \prime}\right), 113 . .6\left(\mathrm{C}-8^{\prime \prime \prime}\right), 166.1\left(\mathrm{C}-9^{\prime \prime \prime}\right)$. The ${ }^{1} \mathrm{H}$ - and ${ }^{13} \mathrm{C}-\mathrm{NMR}$ spectral data are were in agreement with literature data [21].

7,4'-di-O-methyl isoscutellarein (13), yellow powder; ${ }^{1} \mathrm{H}-\mathrm{NMR}(400 \mathrm{MHz})\left(\mathrm{DMSO}-d_{6}\right) \delta_{\mathrm{H}}: 12.42(\mathrm{~s}, 1 \mathrm{H}$, 5-OH), $6.54(s, 1 \mathrm{H}, \mathrm{Hz}, \mathrm{H}-6), 6.85(s, 1 \mathrm{H}, \mathrm{Hz}, \mathrm{H}-3), 8.10\left(d d, J=2.1\right.$ and $\left.6.8 \mathrm{~Hz}, 2 \mathrm{H}, \mathrm{H}-2^{\prime}, 6^{\prime}\right), 7.12$ $\left(d d, J=2.1\right.$ and $\left.6.9 \mathrm{~Hz}, 2 \mathrm{H}, \mathrm{H}-3^{\prime}, 5^{\prime}\right), 3.84\left(\mathrm{~s}, 3 \mathrm{H}, \mathrm{OMe}-4^{\prime}\right), 3.89\left(\mathrm{~s}, 3 \mathrm{H}, \mathrm{OMe}-7^{\prime}\right) ;{ }^{13} \mathrm{C}-\mathrm{NMR}(100 \mathrm{MHz}$, DMSO- $d_{6}$ ): 163.5 (C-2), 103.0 (C-3), 182.4 (C-4), 153.1 (C-5), 95.7 (C-6), 154.4 (C-7), 126.3 (C-8), 144.5 (C-9), 103.9 (C-10), $123.0\left(\mathrm{C}-1^{\prime}\right), 128.5\left(\mathrm{C}-2^{\prime} / 6^{\prime}\right), 114.6\left(\mathrm{C}-3^{\prime} / 5^{\prime}\right), 163.5\left(\mathrm{C}-4^{\prime}\right), 55.6\left(\mathrm{OMe}-4^{\prime}\right), 56.4$ (OMe-7). The NMR spectral data were in agreement with literature data [21].

7,4'-di-O-methyl-8-O-sulphate flavone (14), yellow powder; ${ }^{1} \mathrm{H}-\mathrm{NMR}\left(300 \mathrm{MHz} \delta_{\mathrm{H}}: 12.85(\mathrm{~s}, 1 \mathrm{H}, 5-\mathrm{OH})\right.$, $6.52(s, 1 \mathrm{H}, \mathrm{Hz}, \mathrm{H}-6), 6.82(s, 1 \mathrm{H}, \mathrm{Hz}, \mathrm{H}-3), 8.27\left(d, J=9.8 \mathrm{~Hz}, 2 \mathrm{H}, \mathrm{H}-2^{\prime}, 6^{\prime}\right), 7.07\left(d, J=8.9 \mathrm{~Hz}, 2 \mathrm{H}, \mathrm{H}-3^{\prime}\right.$, $\left.5^{\prime}\right), 3.86\left(\mathrm{~s}, 3 \mathrm{H}, \mathrm{OMe}-4^{\prime}\right), 3.85$ (s, 3H, OMe-7'); ${ }^{13} \mathrm{C}-\mathrm{NMR}(75 \mathrm{MHz})\left(\mathrm{DMSO}-d_{6}\right): 164.3(\mathrm{C}-2), 102.7$ (C-3), 182.1 (C-4), 156.9 (C-5), 96.0 (C-6), 159.1 (C-7), 122.7 (C-8), 149.4 (C-9), 103.7 (C-10), 123.1 (C-1'), 129.1 $\left(\mathrm{C}-2^{\prime} / 6^{\prime}\right), 116.3\left(\mathrm{C}-3^{\prime} / 5^{\prime}\right), 162.3\left(\mathrm{C}-4^{\prime}\right), 55.5\left(\mathrm{OMe}-4^{\prime}\right), 56.4(\mathrm{OMe}-7)$. The NMR spectral data were in agreement with literature data [21].

\subsection{Biological Assay}

The mean mortalities of A. aegypti larvae (L4) at each Crude Ethanolic Extract (CEE) concentration are depicted in Table 2. A concentration of $10.0 \mathrm{mg} / \mathrm{mL}$ was able to kill $100 \%$ of the larvae. Concentrations of $7.5,5.0,3.5,3.0,2.5,1.0$ and $0.1 \mathrm{mg} / \mathrm{mL}$ caused the death of $80.0 \%, 77.5 \%, 68.3 \%$, $66.6 \%, 26.6,11.6 \%$ and $0 \%$, respectively. Only concentrations of 2.5 and $10.0 \mathrm{mg} / \mathrm{mL}$ were considered statistically different $(p<0.05)$, as can be seen in Figure 2. The calculated $\mathrm{LC}_{50}$ of CEE was $2.983 \mathrm{mg} / \mathrm{mL}$.

Table 2. Mean number of mortalities of A. aegypti larvae (L4) in different concentrations of Crude Ethanolic Extract (CEE) of H. velutina.

\begin{tabular}{ccc}
\hline Concentration $(\mathbf{m g} / \mathbf{m L})$ & Mean Mortality $(\mathbf{n})$ & Standard Deviation (Triplicate) \\
\hline $0.1(\mathrm{a})^{*}$ & 0 & 0 \\
$1.0(\mathrm{a})$ & $2.3(11.6 \%)$ & 0.57 \\
2.5 & $5.3(26.6)$ & 1.15 \\
$3.0(\mathrm{~b})(\mathrm{c})$ & $13.3(66.6 \%)$ & 0.57 \\
$3.5(\mathrm{~b})(\mathrm{d})(\mathrm{e})$ & $13.6(68.3 \%)$ & 1.52 \\
$5.0(\mathrm{c})(\mathrm{d})(\mathrm{f})$ & $15.5(77.5 \%)$ & 1.29 \\
$7.5(\mathrm{e})(\mathrm{f})$ & $16.0(80.0 \%)$ & 1.26 \\
10.0 & $20(100 \%)$ & 0 \\
Negative Control & 0 & 0 \\
Positive Control & $20(100 \%)$ & 0 \\
\hline
\end{tabular}

${ }^{*}$ Means followed by the same letter are not significantly different by Tukey test, at a level of $5 \%$ of probability. 


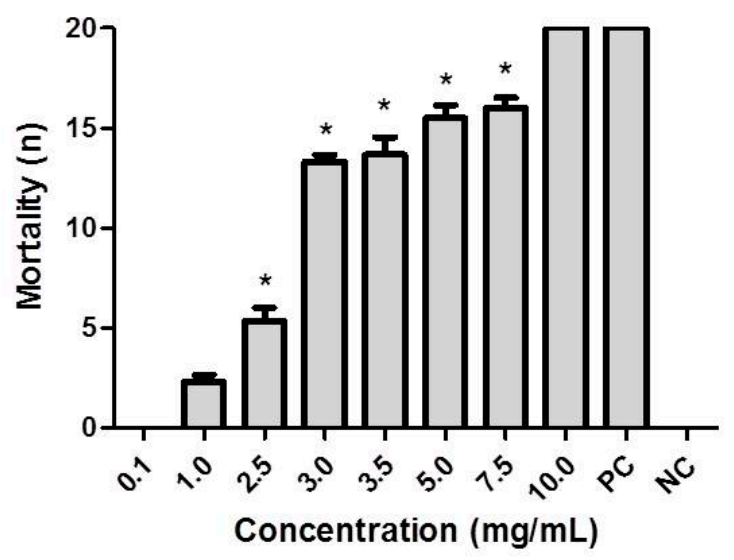

Figure 2. Larvicidal activity of different concentrations of Crude Ethanolic Extract (CEE) of H. velutina on A. aegypti larvae after $24 \mathrm{~h}$. PC = Positive Control, NC = Negative Control. ${ }^{*}$ ) Indicates results that are significantly different from controls.

\section{Discussion}

Sample 15 was obtained as a yellow powder. Its IR spectra recorded bands at $3466 \mathrm{~cm}^{-1}$, characteristic of hydroxyl axial deformation, and in the region of $2851 \mathrm{~cm}^{-1}$, typical of C-H from a methoxyl group [21]. It could be seen that there were absorptions at 1606, 1500 and $1450 \mathrm{~cm}^{-1}$, indicating a $\mathrm{C}=\mathrm{C}$ of aromatic compounds, as well as at $1697 \mathrm{~cm}^{-1}$, suggestive of $\mathrm{C}=\mathrm{O}$ of conjugated and bridged ketones present in flavonoids [22]. The absorbances of asymmetric stretches at $1384 \mathrm{~cm}^{-1}$ and symmetrical stretches at $1182 \mathrm{~cm}^{-1}$ indicated the occurrence of an $\mathrm{S}=\mathrm{O}$ group, and together with absorptions at 1026 to $1001 \mathrm{~cm}^{-1}$, assigned to an S-O bond, pointed to the possible presence of a sulphate group in the structure [22].

The ${ }^{1} \mathrm{H}-\mathrm{NMR}$ spectra, obtained in DMSO- $d_{6}$ exhibited a busy set of signals in the aromatic region, with different intensities suggesting that 15 might be a mixture of compounds. The signals of $\delta_{\mathrm{H}} 8.26$ $(\mathrm{dd}, J=9.0$ and $1.75 \mathrm{~Hz}, 2 \mathrm{H})$ coupled with $\delta_{\mathrm{H}} 7.09(\mathrm{~d}, J=9.0 \mathrm{~Hz}, 2 \mathrm{H})$ and $8.13(\mathrm{~d}, J=8.9 \mathrm{~Hz}, 2 \mathrm{H})$ with $6.86(\mathrm{~d}, J=8.8 \mathrm{~Hz}, 2 \mathrm{H})$ suggested two $\mathrm{AA}^{\prime} \mathrm{BB}^{\prime}$ systems. The first system was indicative of a methoxyl substituent in $\mathrm{C}-4^{\prime}$, deshielding the $3^{\prime}, 5^{\prime}$ and $2^{\prime}, 6^{\prime}$ positions. The second system proposed the presence of an $\mathrm{OH}-4^{\prime}$ group, which protects $\mathrm{H}-3^{\prime}, 5^{\prime}$ and $\mathrm{H}-2^{\prime}, 6^{\prime}$. The substituents were later confirmed by $2 \mathrm{D}$ NMR analysis. The additional presence in the ${ }^{1} \mathrm{H}-\mathrm{NMR}$ spectra of signals at $\delta_{\mathrm{H}} 7.56(\mathrm{~d}, J=2.2 \mathrm{~Hz}$, $1 \mathrm{H}), 7.06(\mathrm{~d}, J=8.5 \mathrm{~Hz}, 1 \mathrm{H})$ and $7.83(\mathrm{dd}, J=2.2$ and $8.5 \mathrm{~Hz}, 1 \mathrm{H})$, compatible with an ABX system [21], suggested the existence of a third molecule in the mixture (Table 1 ). The ${ }^{1} \mathrm{H}-\mathrm{NMR}$ and IR spectral data provided evidence for the presence of a mixture of three flavones, renamed compounds 14, 15a and $15 b$, respectively. A singlet at $\delta_{\mathrm{H}} 3.82$, with an intensity for three methoxyls in a chemically and magnetically equivalent environment, was consistent with the presence of this group at C-7 of the flavone nucleus of the three molecules. The signal at $\delta_{\mathrm{H}} 3.84$ was attributed to the methoxyl group of $\mathrm{C}-4^{\prime}$ of an $\mathrm{AA}^{\prime} \mathrm{BB}^{\prime}$ system, and the singlet at $\delta_{\mathrm{H}} 3.85$ suggested the $\mathrm{ABX}$ system, with $\mathrm{OCH}_{3}-4^{\prime}$ and $\mathrm{OH}-3^{\prime}$, later confirmed by 2D NMR [21].

The APT ${ }^{13} \mathrm{C}-\mathrm{NMR}$ spectrum revealed weak peaks and aligned with HMBC, HMQC and COSY spectra, thereby allowing identification of the substances and confirming the position of the substituents. The ${ }^{13} \mathrm{C}-\mathrm{NMR}$ data showed carbons with high intensity at $\delta_{C} 129.3 / 115.9$, characteristic values for the $2^{\prime} / 6^{\prime}$ and $3^{\prime} / 5^{\prime}$ carbons of the para-substituted $\mathrm{B}$ ring of flavonoids assigned to the major compound. The ${ }^{13} \mathrm{C}$-NMR spectrum showed methoxyl carbons at $\delta_{\mathrm{C}} 56.4,56.4$ and 55.7.

The HRMS of the compounds were obtained by LC-HRMS, confirming the $O$-sulphate group in 14, 15a and 15b. The accurate mass for compound 14 (minor compound) as an $[\mathrm{M}-\mathrm{H}]^{-}$ion, found with a retention time (RT) of $4.90 \mathrm{~min}$, was $393.0260\left(\mathrm{C}_{16} \mathrm{H}_{14} \mathrm{O}_{9} \mathrm{~S}\right)$; for the major compound, 15a, the $[\mathrm{M}-\mathrm{H}]^{-}$ ion (RT: $3.63 \mathrm{~min}$ ) was $379.0129\left(\mathrm{C}_{16} \mathrm{H}_{13} \mathrm{O}_{9} \mathrm{~S}\right)$; and for compound $\mathbf{1 5 b}$, also as an $[\mathrm{M}-\mathrm{H}]^{-}$ion $(\mathrm{RT}$ : 
$4.07 \mathrm{~min})$ the mass found to be $409.0236\left(\mathrm{C}_{17} \mathrm{H}_{15} \mathrm{O}_{10} \mathrm{~S}\right)$. The obtained results confirmed the $\mathrm{O}$-sulphate group in the three molecules of the mixture and contributed to their identification.

Compound 14 was identified as 7,4'-di-O-methyl-8-O-sulphate-isoscutelarein, previously reported from Wissadula periplocifolia [21] and Sidastrum micranthum [23], both belonging to the Malvaceae family and here reported in the Sterculiaceae family. Compound 15a was identified as 5,4'-di-hydroxy-7-methoxy-8-O-sulphate flavone, or Mariahine (named in honor of the author's mother) and compound $\mathbf{1 5 b}$ was identified as 5,3'-di-hydroxy-7, $4^{\prime}$-dimethoxy-8-O-sulphate flavone, named as Condadine (in honor of the author's hometown). Compounds $15 \mathbf{a}$ and $\mathbf{1 5} \mathbf{b}$ are being reported here for the first time in the literature.

Flavonoids with O-sulphated groups attached to the main skeleton are probably the most uncommon flavonoid derivatives and are found in few vegetal families. This is the first report of sulphated flavonoids in the Sterculiaceae family. These compounds are produced by cytosolic sulphotransferase (SOT) enzymes able to produce sulphated flavonoids as well as other sulphated metabolites. Different types of SOTs exist in the Golgi apparatus, where their role is to attach sulphate to protein and sugar structures [24].

The bioassays were performed using the concentration of $0.1 \mathrm{mg} / \mathrm{mL}$, where no activity was observed. The concentration was gradually increased to reach a satisfactory mortal concentration. The larvae (L4) presented with compromised mobility and lethargy, followed by complete paralysis. This result became more intense when the CEE concentration was raised. Similar results have been described by other studies with the species Swinglea glutinosa [25], Copaifera reticulata and Copaifera langsdorfii (Leguminosae) [26,27].

According to Tukey's testing, the concentrations 0.1 and $1.0 \mathrm{mg} / \mathrm{mL}$ did not differ significantly, and neither did the concentrations $3.0,3.5,3.5,5.0$ or $7.5 \mathrm{mg} / \mathrm{mL}$ when compared to $5.0 \mathrm{mg} / \mathrm{mL}$ and $7.5 \mathrm{mg} / \mathrm{mL}$ (Figure 2). This similarity of results from tested concentrations has already been reported in other studies [28-31]. The larvicidal percentage reached $100 \%$ after $24 \mathrm{~h}$ of exposure and the dose of $10.0 \mathrm{mg} / \mathrm{mL}$ was significantly more effective versus the other concentrations and negative control group.

According to the statistical analysis, the $\mathrm{LC}_{50}$ for the H. velutina aerial parts CEE was $2.983 \mathrm{mg} / \mathrm{mL}$. The closest concentration tested was $3.0 \mathrm{mg} / \mathrm{mL}$ which killed 13.3 larvae (mean) corresponding to $66.6 \%$ of larvae. This concentration was much lower than those reported in previous studies evaluating larvicidal activity of extracts, such as Croton linearifolius (Euphorbiaceae), which presented an $\mathrm{LC}_{50}$ value of $17.420 \mathrm{mg} / \mathrm{mL}$ [29], and Trichilia pallida (Meliaceae) with an $\mathrm{LC}_{50}$ of $4.660 \mathrm{mg} / \mathrm{mL}$ [32]. The dose found was higher when compared to the Duguetia furfuraceae (Anonaceae) dose of $597 \mathrm{mg} / \mathrm{mL}$ [33] and the Vitex gardneriana (Verbenaceae) dose of $369 \mathrm{mg} / \mathrm{mL}$ [34].

The $\mathrm{LC}_{10}, \mathrm{LC}_{50}$ and $\mathrm{LC}_{90}$ calculated herein from the CEE of the aerial parts of $H$. velutina were more promising than the results from an earlier study [11], in which extracts of the stem and roots of the same species were evaluated (Table 3). This study shows that the aerial parts have significantly more larvicidal activity, arousing interest in evaluating the larvicidal activity of its constituents as well as the mechanisms of action involved. This difference in activity, depending on the part of the plant used, is common [35]; as exemplified by the larvicidal activity against $A$. aegypti, of the ethanolic extract of the leaves or roots of Piper alatabaccum (Piperaceae), with the leaves $\mathrm{LC}_{50}$ found as $869 \mathrm{mg} / \mathrm{mL}$, while the $\mathrm{LC}_{50}$ value for the roots was $33 \mathrm{mg} / \mathrm{mL}$. A study with Azadirachta indica (Meliaceae) showed there was a greater larvicidal potential for the ethanol extract of leaves $\left(\mathrm{LC}_{50}=50 \mathrm{mg} / \mathrm{mL}\right)$ when compared with the root extract $\left(\mathrm{LC}_{50}=600 \mathrm{mg} / \mathrm{mL}\right)[36]$.

Bioactive plant extracts usually present a synergistic or additive action by their compounds, being necessary for the subsequent evaluation of fractions and isolated compounds in order to determine if the complex matrix or the isolated compounds are more efficacious as larvicides [37]. Undoubtedly, the larvicidal activity of the H. velutina CEE in low concentrations justifies interest in using it as a domestic larvicide to combat $A$. Aegypti [37], a vector insect of severe viral diseases, such as dengue and Zika. 
Table 3. Lethal concentrations ( $\mathrm{LC}_{10}, \mathrm{LC}_{50}$ and $\mathrm{LC}_{90}$ ) of Helicteres velutina $\mathrm{CEE}$ against Aedes aegypti larvae (24 h of exposure) [11].

\begin{tabular}{cccc}
\hline Used Part & LC $_{\mathbf{1 0}}$ & LC $_{\mathbf{5 0}}$ & LC $_{\mathbf{9 0}}$ \\
\hline Stem * & $60.406 \mathrm{mg} / \mathrm{mL}$ & $138.896 \mathrm{mg} / \mathrm{mL}$ & $319.372 \mathrm{mg} / \mathrm{mL}$ \\
Roots * & $73.029 \mathrm{mg} / \mathrm{mL}$ & $171.683 \mathrm{mg} / \mathrm{mL}$ & $403.607 \mathrm{mg} / \mathrm{mL}$ \\
Aerial parts & $0.965 \mathrm{mg} / \mathrm{mL}$ & $2.983 \mathrm{mg} / \mathrm{mL}$ & $9.691 \mathrm{mg} / \mathrm{mL}$ \\
\hline \multicolumn{4}{c}{ * Santos et al., $2012[11]}$.
\end{tabular}

\section{Materials and Methods}

\subsection{General}

For the isolation and analysis of the compounds, the adsorbents Silica gel 60 (Merck), silica flash and/or Sephadex LH-20 (Merck, Kenilworth, NJ, USA) were used.

Infrared spectral data were obtained with a Perkin-Elmer FT-IR-1750 (Perkin-Elmer, São Paulo, $\mathrm{SP}$, Brazil) using $1.0 \mathrm{mg}$ of sample in $\mathrm{KBr}$ pellets measured in $\mathrm{cm}^{-1}$.

Nuclear magnetic resonance spectra were obtained using the spectrometers VARIAN-SYSTEM (Palo Alto, CA, USA) $500 \mathrm{MHz}\left({ }^{1} \mathrm{H}\right)$ and $125 \mathrm{MHz}\left({ }^{13} \mathrm{C}\right.$ ) , BRUKER 500 (Bruker, Coventry, UK) MHz $\left({ }^{1} \mathrm{H}\right.$ ) and $100 \mathrm{MHz}\left({ }^{13} \mathrm{C}\right)$ at Multiuser Laboratory Center of Characterization and Analysis (LMCA-UFPB) and VARIAN-GEMINI $300 \mathrm{MHz}\left({ }^{1} \mathrm{H}\right)$ and $75 \mathrm{MHz}\left({ }^{13} \mathrm{C}\right)$ at the Centro Nordestino de Aplicação e Uso da Ressonância Magnética Nuclear (CENAUREMN-UFC). Deuterated solvents were used in the dissolution of the samples for NMR. Chemical shifts $(\delta)$ were recorded in ppm (parts per million) and coupling constants $(J)$ in $\mathrm{Hz}$.

\subsection{Collection, Extraction, and Compound Isolation}

The aerial parts of H. velutina were collected in February 2015 in Serra Branca/Raso da Catarina (Jeremoabo City, Bahia, $09^{\circ} 53^{\prime} 15.5^{\prime \prime} ; 09^{\circ} 44^{\prime} 34.6^{\prime \prime} \mathrm{S}$ and $38^{\circ} 49^{\prime} 36,1^{\prime \prime} ; 38^{\circ} 52^{\prime} 20.4^{\prime \prime} \mathrm{W}$ ) [38]. The material was identified by Prof. Adilva de Souza Conceição (UNEB) and a specimen voucher (28709-1) was kept in the Herbarium of the State University of Bahia (HUNEB, Paulo Afonso Collection).

The aerial parts of $H$. velutina were oven dried at $40{ }^{\circ} \mathrm{C}$ and $1976.0 \mathrm{~g}$ of the powder was macerated with $95 \%$ ethanol $(5 \mathrm{~L})$ for $72 \mathrm{~h}$. The extract solution was dried under reduced pressure at $40{ }^{\circ} \mathrm{C}$ and provided $39.7 \mathrm{~g}$ of CEE that was submitted to liquid-liquid chromatography using hexane, dichloromethane, ethyl acetate and n-butanol, resulting in their respective phases and a hydroalcoholic phase.

The hexane phase (11.0 g) was chromatographed in a silica gel column (CC), followed by medium pressure chromatography (MPC) with silica flash using hexane, ethyl acetate and methanol in increasing polarity mixtures. This process resulted in the isolation of substances $1(7 \mathrm{mg}), \mathbf{2}(13 \mathrm{mg})$, 3 (30.0 mg), 4 (4a and $\mathbf{4 b}-30.0 \mathrm{mg}), \mathbf{5}(12.0 \mathrm{mg}), \mathbf{7}(17.0 \mathrm{mg}), \mathbf{8}(22.0 \mathrm{mg})$ and $\mathbf{9}(6.0 \mathrm{mg})$.

The dichloromethane phase $(8.0 \mathrm{~g})$ was chromatographed in a silica flash CC using petroleum ether, dichloromethane and methanol in increasing polarity mixtures. The resulting fractions were analyzed and combined by similarity on TLC. Fractions $24 / 30(815 \mathrm{mg})$ were chromatographed in flash silica CC with an elution system composed of hexane, ethyl acetate and methanol. The procedure resulted in the isolation of compounds $\mathbf{1 0}(8 \mathrm{mg})$ and $\mathbf{1 1}(6 \mathrm{mg})$.

The polar fractions were chromatographed in Sephadex (LH-20) CC employing, as the mobile phase, methanol and methanol:chloroform (1:1), providing compounds 6 (11 mg), $12(85 \mathrm{mg}), 13$ (32 mg), 14 (37 mg) and $\mathbf{1 5}(\mathbf{1 4}, \mathbf{1 5 a}$ and $\mathbf{1 5 b})(15 \mathrm{mg})$.

LC-MS (Accela 600 HPLC system combined with an Exactive (Orbitrap)-Thermo Fisher Scientific (Bremen, Germany)) was used to obtain the high-resolution mass spectra in negative or positive mode. The samples were solubilized in methanol (HPLC grade) to obtain a concentration of $1 \mathrm{mg} / \mathrm{mL}$. The injection volume was $20 \mu \mathrm{L}$. The column used was a reverse phase ACE C-18 $(150 \times 3 \mathrm{~mm}, 3 \mu \mathrm{m})$ from HiChrom (Reading, UK). The mobile phase gradient was a mixture of $0.1 \%$ formic acid in $\mathrm{H}_{2} \mathrm{O}$ (solvent A) and acetonitrile (solvent B). The flow rate was $300 \mu \mathrm{L} / \mathrm{min}$. The method is summarized 
in Table 4. The obtained results were analyzed using Xcalibur 2.2 (Thermo Fisher Scientific) (Bremen, Germany).

Table 4. LC-HRMS gradient method.

\begin{tabular}{ccc}
\hline Time (min) & A $\%$ & B $\%$ \\
\hline 0 & 75 & 25 \\
15 & 25 & 75 \\
\hline
\end{tabular}

\subsection{Biological Assay}

The larvicidal activity of the CEE of $H$. velutina was evaluated following the recommendations of the World Health Organization (1970). The fourth-stage A. aegypti larvae (L4) (Rockefeller strain) were obtained from the Laboratory of Biotechnology Applied to Parasites and Vectors, Biotechnology Center, Federal University of Paraiba.

H. velutina CEE was diluted in distilled water $(10 \mathrm{~mL})$ at different concentrations $(0.1$ to $10 \mathrm{mg} / \mathrm{mL})$. Twenty L4-stage larvae were transferred into Falcon tubes containing the solutions of H. velutina CEE. One control group was prepared using only water. The positive control group was prepared using a solution of the insecticides Imiprothrin $0.02 \%$, Permethrin $0.05 \%$ and Esbiothrin $0.1 \%$. The tubes were incubated for $24 \mathrm{~h}$ at $28 \pm 4{ }^{\circ} \mathrm{C}$, over $12 \mathrm{~h}$ of natural light and $12 \mathrm{~h}$ of darkness. Larvae mortality was verified after $24 \mathrm{~h}$ of incubation. All tests were carried out in triplicate. GraphPad Prism 5.0 software (GraphPad Software, San Diego, CA, USA) was used to calculate $\mathrm{LC}_{10}, \mathrm{LC}_{50}$ and LC90. Analysis of variance (ANOVA) and Tukey's test $(p<0.05)$ were applied to determine significant differences between groups.

\section{Conclusions}

The phytochemical study of the crude ethanolic extract of $H$. velutina aerial parts led to the identification of 16 compounds. Among them were one fatty acid, one aliphatic alcohol, four chlorophyll derivatives, one steroid, triterpenes, a lignan, and flavonoids, highlighting the novel sulphated flavonoids, 5,4'-di-hydroxy-7-methoxy-8-O-sulphate flavone (mariahine) (15a) and 5,3'-di-hydroxy-7, $4^{\prime}$-methoxy-8-O-sulphate flavone (condadine) (15b). The present work contributed to consolidating the chemotaxonomic knowledge of the Sterculiaceae family, reporting for the first time the production of sulphated flavonoids in this family. The CEE of H. velutina aerial parts exhibited robust larvicidal activity against $A$. aegypti larvae, demonstrating that the extract can be useful for developing domestic larvicides to combat A. Aegypti [37], a vector insect of severe viral diseases, such as dengue and Zika.

Supplementary Materials: The following are available online.

Author Contributions: D.A.F., M.S.R.S., Y.C.F.T. and M.d.F.V.d.S. isolated and identified the compounds; T.M.S.S. performed LC-MS assay; A.S.C. and J.B.L. collected and identified the plant; D.A.F., F.C.N. and L.H.G.O. performed the biological assay.

Funding: This research was funded by MCT-INSA/National Council for Scientific and Technological Development $(\mathrm{CNPq})$; Universal $(\mathrm{CNPq})$ and Coordination for the Improvement of Higher Education Personnel (CAPES).

Acknowledgments: The authors thank CAPES and MCT-INSA/CNPq/CT for financial support. The authors are grateful to the Multiuser Laboratory Center of Characterization and Analysis (LMCA-UFPB) and CENAUREM-UFC for obtaining the spectra, and to the Center of Biotechnology (BIOTEC-UFPB) for assistance with the biological assay.

Conflicts of Interest: The authors declare no conflicts of interest.

\section{References}

1. Cruz, F.R.; Esteves, G.L. Melastomataceae, Polygonaceae, Sapindaceae e Sterculiaceae. In Flora Fanerogâmica do Estado de São Paulo Online; Martins, S.E., Wanderley, M.G.L., Shepherd, G.J., Giulietti, A.M., Melhem, T.S., Eds.; Instituto de Botânica: São Paulo, Brasil, 2009; Volume 6, pp. 257-284. ISBN 978-85-7523-057-2. 
2. Muqarrabun, L.M.R.A.; Ahmat, N. Medicinal uses, phytochemistry and pharmacology of Family Sterculiaceae: A review. Eur. J. Med. Chem. 2015, 92, 514-530. [CrossRef] [PubMed]

3. The Angiosperm Phylogeny Group (APG). An update of the Angiosperm Phylogeny Group classification for the orders and families of flowering plants: APG IV. Bot. J. Linn. Soc. 2016, 181, 1-20. [CrossRef]

4. Cruz, F.R. Sterculiaceae Vent. no Estado de São Paulo. Master's Thesis, Instituto de Botânica da Secretária de Estado do Meio Ambiente, São Paulo, Brasil, 2007.

5. Chen, W.; Tang, W.; Lou, L.; Zhao, W. Pregnane, coumarin and lupine derivatives and cytotoxic constituents from Helicteres angustifolia. Phytochemistry 2006, 67, 1041-1047. [CrossRef] [PubMed]

6. Chen-Zong, T.; Lee, S.W.; Chen-Chiu, M. Cucurbitacin B 2-Sulfate and Cucurbitacin Glucosides from the Root Bark of Helicteres angustifolia. Chem. Pharm. Bull. 2006, 54, 1605-1607. [CrossRef]

7. Wang, G.C.; Li, T.; Wei, Y.R.; Zhang, Y.B.; Li, Y.L.; Sze, S.C.W.; Ye, W.C. Two pregnane derivates and a quinolone alkaloid from Helicteres angustifolia. Fitoterapia 2012, 83, 1643-1647. [CrossRef] [PubMed]

8. Kumar, N.; Singh, A.K. Plant profile, phytochemistry and pharmacology of Avartani (Helicteres isora Linn.): A review. Asian Pac. J. Trop. Biomed. 2014, 4, 22-26. [CrossRef] [PubMed]

9. Kamiya, K.; Saiki, Y.; Hama, T.; Fujimoto, Y.; Endang, H.; Umar, M.; Satake, T. Flavonoid glucuronides from Helicteres isora. Phytochemistry 2001, 57, 297-301. [CrossRef]

10. Huang, Q.; Huang, R.; Wei, L.; Chen, Y.; Lv, S.; Liang, C.; Zhang, X.; Yin, F.; Li, H.; Zhuo, L.; et al. Antiviral activity of methyl helicterate isolated from Helicteres angustifolia (Sterculiaceae) against hepatitis B virus. Antivir. Res. 2013, 100, 373-381. [CrossRef] [PubMed]

11. Santos, E.A.; Carvalho, C.M.; Costa, A.L.S.; Conceição, A.S.; Moura, F.B.P.; Santana, A.E.G. Bioactivity evaluation of plants extracts used in indigenous medicine against the snail, Biomphalaria glabrata, and the larvae of Aedes aegypti. Evid.-Based Complement. Altern. Med. 2012, 1, 1-9. [CrossRef]

12. Brito-Filho, S.G.; Maciel, J.K.S.; Teles, Y.C.F.; Fernandes, M.M.M.S.; Chaves, O.S.; Ferreira, M.D.L.; Fernandes, P.D.; Felix, L.P.; Cirino, I.C.S.; Siqueira-Júnior, J.P.; et al. Phytochemical study of Pilosocereus pachycladus and antibiotic-resistance modifying activity of syringaldehyde. Braz. J. Pharmacogn. 2017, 27, 453-458. [CrossRef]

13. Gomes, R.A.; Teles, Y.C.F.; Pereira, F.O.; Rodrigues, L.A.S.; Lima, E.O.; Agra, M.F.; Souza, M.F.V. Phytoconstituents from Sidastrum micranthum (A. St.-Hil.) Fryxell (Malvaceae) and antimicrobial activity of pheophytin a. Braz. J. Pharm. Sci. 2015, 4, 861-867. [CrossRef]

14. Chaves, O.S.; Gomes, R.A.; Tomaz, A.C.A.; Fernandes, M.G.; das Graças Mendes Junior, L.; de Fátima Agra, M.; Braga, V.A.; Souza, M.F.V. Secondary Metabolites from Sida rhombifolia L. (Malvaceae) and the Vasorelaxant Activity of Cryptolepinone. Molecules 2013, 18, 2769-2777. [CrossRef] [PubMed]

15. Hossain, R.; Sultana, R.; Cloudhary, M.I.; Zaman, S. Xanthone from the fruits of Terminalia arjuna. J. Sci. Res. 2016, 2, 1-7. [CrossRef]

16. Seebacher, W.; Simic, N.; Weis, R.; Saf, R.; Kunert, O. Complete assignments of ${ }^{1} \mathrm{H}$ and ${ }^{13} \mathrm{C}$ resonances of oleanolic acid, $18 \alpha$-oleanolic acid, ursolic acid and their 11-oxo derivates. Magn. Reson. Chem. 2003, 41, 636-638. [CrossRef]

17. Costa, V.C.O. Contribuição ao Conhecimento Químico de Espécies de Hyptis com Ocorrência no Semiárido Paraibano: Hyptis macrostachys Benth. E Hyptis umbrosa Salzm. Ph.D. Thesis, Programa de Pós-Graduação em Produtos Naturais e Sintéticos Bioativos, Universidade Federal da Paraíba, João Pessoa, Brasil, 2013.

18. Vieira-Filho, S.A.; Duarte, L.P.; Silva, G.D.F.; Howarth, O.W.; Lula, I.S. 3-(Stearyloxy)olean-12-ene from Austroplenckia populnea: Structure Elucidation by 2D-NMR and Quantitative 13C-NMR Spectroscopy. Helv. Chim. Acta 2003, 86, 3445-3449. [CrossRef]

19. Yi, B.; Hu, L.; Mei, W.; Zhou, K.; Wang, H.; Luo, Y.; Wei, X.; Dai, H. Antioxidant Phenolic Compounds of Cassava (Manihot esculenta) from Hainan. Molecules 2010, 16, 10157-10167. [CrossRef] [PubMed]

20. Barreto, M.B.; Gomes, C.L.; Freitas, J.V.B.; Pinto, F.C.L.; Silveira, E.R.; Gramosa, N.V. Flavonoides e terpenoides de Croton muscicarpa (Euphorbiaceae). Quím. Nova 2013, 6, 675-679. [CrossRef]

21. Teles, Y.C.F.; Horta, C.C.R.; Agra, M.F.; Siheri, W.; Boyd, M.; Igoli, J.O.; Gray, A.I.; Souza, M.F.V. New Sulphated Flavonoids from Wissadula periplocifolia (L.) C. Presl (Malvaceae). Molecules 2015, 20, 20161-20172. [CrossRef] [PubMed]

22. Pavia, D.L.; Lampman, G.M.; Kriz, G.S.; Vyvyan, J.R. Introdução à Espectroscopia, 4th ed.; Cengage Learning: São Paulo, Brazil, 2010; pp. 169-342. ISBN 978-85-221-0708-7. 
23. Buchholz, H.; Wirth, C.; Carola, C.; Alves Fontes, R. Flavonoid Derivative. U.S. Patent 20,070,134,172A1, 14 July 2007.

24. Teles, Y.C.F.; Souza, M.S.R.; Souza, M.F.V. Sulphated Flavonoids: Biosynthesis, Structures, and Biological Activities. Molecules 2018, 23, 480-491. [CrossRef] [PubMed]

25. Cabral, S.S. Atividade Larvicida do Extrato Bruto de Swinglea glutinosa Evidenciada Pelas Alterações Morfohistológicas em Larvas de Aedes aegypti (Diptera, Culicidae). Master's Thesis, Pós graduação em Biologia da Relação Parasito-Hospedeiro, Universidade Federal de Goiás, Goiânia, Brasil, 2015.

26. Abed, R.A.; Cavasin, G.M.; Silva, H.H.G.; Silva, I.G. Alterações Morfohistológicas em Larvas de Aedes aegypti (Linnaeus, 1762) (Diptera, Culicidae) causadas pela atividade larvicida do óleo-resina da planta medicinal Copaifera reticulata Ducke (Leguminosae). Rev. Patol. Trop. 2007, 36, 75-86. [CrossRef]

27. Santos, D.B. Atividade Larvicida da Copaifera langsdorffii (Leguminosae), Evidenciada Pelas Alterações Morfohistológicas em Aedes aegypti (Diptera, Culicidae). Master's Thesis, Pós-Graduação em Biologia da Relação Parasito-Hospedeiro, Universidade Federal de Goiás, Goiânia, Brasil, 2015.

28. Darmali, L.; Silva, C.B.; Campos, F.M.M.; Bursi, L.M.; Nascimento, K.F.; Jesus, C.; Dias, J.F.G.; Dallarmi, M.M.; Gomes, O.M.; Zanin, S.M.W. Larvicidal activity of Dalbergia brasiliensis (Fabaceae-Papilioideae) on Aedes aegypti. Afr. J. Phram. Pharmacol. 2015, 9, 881-885. [CrossRef]

29. Silva, S.L.C.; Gualberto, S.A.; Carvalho, K.S.; Fries, D.D. Avaliação da atividade larvicida de extratos obtidos do caule de Croton linearifolius Mull. Arg. (Euphorbiaceae) sobre larvas de Aedes aegypti (Linnaeus, 1762) (Diptera: Culicidae). Biotemas 2014, 27, 79-85. [CrossRef]

30. Carvalho, G.H.F. Atividade Inseticida do Extrato Bruto Etanólico de Persea americana (Lauraceae) Sobre Larvas e Pupas de Aedes aegypti (Diptera, Culicideae). Master's Thesis, Pós-Graduação em Biologia da Relação Parasito-Hospedeiro, Universidade Federal de Góias, Goiânia, Brasil, 2011.

31. Oliveira, G.P.; Silva, S.L.C.; Gualberto, S.A.; Cruz, R.C.D.; Carvalho, K.S. Atividade larvicida do extrato etanólico da raiz de Croton linearifolius sobre Aedes aegypti. Encicl. Biosf. Centro Cient. Conhecer 2014, 10, 442-448.

32. Amaro, N.B. Avaliação do Potencial de Extratos Vegetais de Trichilia pallida (Swartz, 1788) (Sapindales: Meliaceae) e Sesamum indicum (L. Linnaeus, 1753) (Lamiales: Pedaliaceae) na Prospecção de Acaricidas Botânicos Para Controle de Rhipicephalus Sanguineus (Latreille, 1806) (Acari: Ixodidae). Master's Thesis, Pós graduação em Medicina Tropical, Universidade Federal de Goiás, Goiânia, Brasil, 2007.

33. Fernandes, R.S. Espacialização da Dengue e os Efeitos dos Extratos de Anonáceas no Controle do Vetor Aedes aegypti (Linnaeus, 1762) (Diptera: Culicidae) em Tangará da Serra, Mato Grosso. Master's Thesis, Pós-graduação em Ciências ambientais, Universidade do Estado de Mato Grosso, Cáceres, Brasil, 2012.

34. Monteiro, L.C.C.F.; Araújo, E.I.M.; Oliveira, A.M.S.; Alves, L.A.; Bertini, L.M. Atividade antioxidante, teor de fenóis e atividade larvicida ao Aedes aegypti de Vitex gardneriana Schauer. Blucher Chem. Proc. 2015, 3, 1-8. [CrossRef]

35. Santana, H.T. Estudo Fitoquímico de Piper alatabaccum Trel \& Yunck, 1950 e Avaliação da Atividade Larvicida Sobre Aedes aegypti Linnaus, 1762 (Diptera: Culicidae) em Condições de Campo Simulado. Master's Thesis, Pós-graduação em Biologia experimental, Universidade Federal de Rondônia, Porto Velho, Brasil, 2012.

36. Nour, A.H.; Sandanasamy, J.D.; Nour, A.H. Larvicidal activity of extracts from diferente parts of Neem (Azadirachta indica) against Aedes aegypti mosquitoes' larvae. Sci. Res. Essays 2012, 7, 2810-2815. [CrossRef]

37. Coelho, A.A.M.; De Paula, J.E.; Espíndola, L.S. Atividade larvicida de Extratos Vegetais sobre Aedes aegypti (L.) (Diptera: Culicidae), em condições de laboratório. BioAssay 2009, 4, 1-6. [CrossRef]

38. Varjão, R.R.; Jardim, J.G.; Conceição, A.S. Rubiaceae Juss. De catinga na APA Serra Branca/Raso da Catarina, Bahia, Brasil. Biota Neotrop. 2013, 13, 105-123. [CrossRef]

Sample Availability: Samples of all isolated compounds are available from the authors. 